\title{
Interpersonal Conflict Management styles on Conflict Sources in Services Settings
}

\author{
Senthil Murugan,T* N.Panchanatham** \\ *Assistant Professor, Department of Business Administration, Arignar Anna Government Arts College for \\ Women, Walajapet. \\ ** Professor, Department of Business Administration, Annamalai University
}

\begin{abstract}
Interpersonal conflict in work place is a potential problem that organizations can neither avoid nor encourage. It's a potential problem faced by the managers cited in literature, observed in practice as well. While eliminating interpersonal conflict from the work place which is a tough task, managing such conflict could be beneficial to organizations such as services enterprises. Hence, the present work is aimed at developing the scheme of things that can be beneficial to the services enterprises in terms of organizational conflict sources and its inadvertent resolution styles. Based on the survey data generated from 550 employees working in various service firms, the outcome of three independent multiple regression model conceived in the present work confirms the existence of dependency relationship between the conflict sources such as Perceived organizational politics, Perceived uncivil behavior, Perceived organizational injustice and the conflict resolution strategies such as integrating style, obliging style, dominating style, avoiding style and compromising style in services settings. The corresponding findings and implications constitute the outcome associated with this work.
\end{abstract}

Keywords: Interpersonal conflict, Conflict Management, Conflict Sources, Integrating style, Obliging style, Dominating style, Avoiding style and Compromising style

\section{Introduction}

Conflict exists when two or more groups disagree about something. These groups are interdependent, meaning that the resolution of the conflict to common satisfaction cannot occur without some joint effort (Suppiah and Rose, 2006). The disagreement may be real or perceived, but it is expressively felt by at least one of the groups. Also, a conflict may or may not result in an observable response (Alper et al., 2000). The lack of openly negative behavior does not indicate conflict free environment. This is because conflict occurs in phases and when it is still latent, the parties may still feel the presence of room for settlement prior to conflict escalation (Tjosvold et al., 2006). Hence, occurring disagreement within organization indicates presence of conflict. In other words conflict or disagreement arises over common goals to attain or means used to accomplish such goals (Cosier and Ruble, 1981). Hence, conflict is a supposed difference of values between two or more groups that results in shared opposition in goals as well as in behavior. It is a process in which one person tries to offset the efforts of other that will result in frustrating the other person for not attaining his goals (Chen and Tjosvold, 2002). The inadvertent conflict management styles that an Individual adopts while handling an Interpersonal conflicts has been classified into 5 different styles such as Integrating, Compromising, Dominating, Obliging and avoiding styles. The exact choice of this style depends on various situations of the conflict that an Individual might encounter like the nature of conflict, priority of conflict and even the sources of conflict. While the organizational sources of conflict is critical in determining the nature of Interpersonal conflict, the choice of an Individual to resolve this conflict in terms of specific conflict management style remains less understood and the present study is aimed at understanding this choice.

\section{Theoretical Background}

\section{2,1 Conflict Management Styles}

On the basis of nature of the individual and situational factors five conflict management styles are identified and suggested as follows:

Integrating style: It allows both conflicting groups and individuals to achieve their desired outcomes where both are in win-win situation. It is opposite of conflict. Conflicting Groups or individuals openly share information, both attempt to listen and develop empathy. Issues are looked at objectively (Rahim et al., 2000).

Compromising style: There is no distinct winner or loser because each conflicting party is expected to give up something of value for a concession. It is effective when the goals can be divided like sharing of resources and emphasis on compromise through bargaining (Rahim and Bonama, 1979). 
Dominating style: It is also termed as confrontation and competing. This style is power oriented and is associated with direct physical aggression, high assertiveness. One conflicting group's or individual's gain is another conflicting group's or individual's loss (Rahim, 1985).

Obliging style: It is also termed as accommodating or smoothing. This style is low on assertiveness and high on cooperativeness. Conflict is resolved by allowing the desire or interest of only conflicting group or individual to prevail (Rahim, 1983). Groups will be self-sacrificing with emphasis on commonalities and saving future relationship.

Avoiding style: This style is also termed as withdrawal or suppression. Groups of conflict fail to address issues and show behaviors such as withdrawal, indifference, evasion, apathy, fight, person ignores disagreement, may be hesitant to talk on issue (Rahim et al., 2001). This way conflict is suppressed. It means that avoiding style shows low concern for self and others.

\subsection{Sources of Conflict in Organizations}

The organizational conflict irrespective of its types is identified as the resultant of the certain organizational dynamics that might exist in various organizations. While organizational dynamics are viewed as the major sources of conflict, the conflicts due to the employee individual differences also contribute to the conflicts and resultant effects of it in most of the organizations (Konovsky, 2000). From the perspectives of establishing conflict control in the organizations, the conflicts due to the individual difference become unmanageable in terms of establishing conflict management procedures. While individual difference is the function of the personality trait of the employees working in the organization, establishing a uniform behavioral pattern among the employees can be achieved by incorporating psychological testing and screening procedure while selecting employees in the organizations. However, controlling the organizational dynamics that might contribute to the conflicts in the organization is a tough task as it revolves in the day to day functional aspects of the organizations. Thus, establishing conflict control in organizations by controlling the organizational dynamics involves the systematic procedure in measuring those organizational dynamics that forms the sources of conflicts in organizations (Lam et al., 2002). Based on the well established studies, some of the organizational dynamics that could form the sources of conflict include Organizational politics, Uncivil behavior and Organizational injustice.

\subsubsection{Organizational Politics}

Politics has been around everywhere from years. Common decision making alone will not work when concern are basically dissimilar, therefore need of political strategies are demanded (Masterson et al.,2000). Politics in an organization are not official, but in other ways directly or indirectly manipulate an organization, improve power and in attaining the targeted goals. In the current scenario, for working in organization high level political skills on conflict management are demanded. A high level political skill does not mean winning at all cost, but the most important thing is to maintain relationship with and among employees while attaining objectives (Drory and Romm, 1988).

Generally, organizational politics are represented and perceived as unhealthy or negative, but managers should know its destructive aspects to minimize harmful effects. Mostly, employees within organizations can dissipate time excessively engaging in political situations. Without political awareness and skill, we face the unavoidable scene of becoming absorbed in bureaucratic power struggle, narrow politics and harsh power struggles, which greatly delay organizational plan, programs, morale, performance and ultimately profit (Eisenberger et al., 1986).

Politics is a part of organizational life, because organizations are made up of different wellbeing that needs to be associated. Political and workplace politics both are quite different. Most of the managers survive and get success due to workplace politics exist in their organization and a person has to engage in such politics. Towards the negative side, a person is said to be political while the individual is engaged in self-serving behavior that is not approved by organization. Such self-serving behavior include going through inappropriate channels to obtain particular favors. These types of actions damage equality of opportunity in the organization but could form better options for politically powerful individuals in the organizations to get things done. However, the resultant of organizational politics could be a potential source of conflict in organizations.

\subsubsection{Uncivil Behavior}

This is a low intensity unusual behavior with unclear plan to harm the target, disobedience of workplace norms for mutual respect and good manners. Uncivil behavior differs from other interpersonal mistreatment due to unclear plan. Hence, in interpersonal mistreatment executor (one person) uses verbal aggression or shouts at the victim (another person), here intention of misdeed is clear i.e. one person deliberately tries to harm another person. However, in uncivil behavior this intention of misdeed is not quite clear e.g. if an employee says hello to his colleague and he doesn't answer as expected. He may be considered a victim of 
colleague, who might thought the executor of incivility; hence it is not clear that any harm was done. Probably that colleague had not heard the employee saying hello. With incivility, the lacuna in clarity of plan makes it difficult to notify (Ferris et al., 1994).

Uncivil behavior can be visible in different form. It can be interpersonal in nature, where executor shows direct uncivil behavior towards another person. The other form may be cyber uncivil behavior which includes computer based communication such as emails, text and social media communication. For instance one person is sending time-based important information to another person via email, but the person at the next end reverts very slow with unclear response or not replying to emails sent by others (Ferris and Kacmar, 1992). However, the resultant of Uncivil behavior could be a potential source of conflict in organizations.

\subsubsection{Organizational Injustice}

Justice in an organization means to find out whether the workers of that organization are treated honestly or the outcomes obtained in the form of product or services and the methods and techniques carried out are fair at workplace. It can be defined as social interaction quality among employees at workplace. Organizational justice is categorized in various forms such as distributive justice, procedural justice, Interpersonal and informational justice etc (Gandz and Murray, 1980).

Distributive justice means the fairness of decision related to outcomes like salary, bonus and promotion for higher jobs, which an employee receives during the tenure relationship with the organization. All employees perceives level of justice by measuring and comparing outcomes received to their inputs, whether outcomes meet their expectations, and comparing their input/outcome ratio to those of their coworkers. Distributive justice is measured by estimating and comparing the outcome to a standard or rule and/or to the outcome by a referent, such as a colleague or past experience (Baron and Joel, 1996).

Procedural justice means to make a decision on common basis. It is the procedure followed fairly at common basis in order to decide outcome received by all employees at same level. If these procedures are found not followed properly by the decision maker or an organization, perception of injustice may arise (Cortina et al., 2001).Interpersonal justice is one of the important tools in organizational relations. Interpersonal communication, honesty, politeness, and respectful behavior, sincerity, and timely explanations, and accepting rules and regulations and all these elements are included in Interpersonal justice. It also finds out those employees who are willing in both outcomes they obtain and the procedures carried out. It also refers the extent of level superiors behave and treat their subordinates with courtesy and fairness in establishing outcomes and implementing procedures (Singh, 2000).

Informational justice means to carry out fair and satisfactory information and explanations which is required to evaluate decision making process. It includes information related to procedures and processes adopted for the basis of outcomes (Andersson and Pearson, 1999).

Interpersonal and informational justice concentrate more on the explanations, information and behaviors of the decision maker, however, procedural and distributive justice concentrate more on general or structural characteristics of procedures or outcomes themselves. Thus, the existence of perceived injustice could be a potential source of conflict in organizations.

\section{Objective}

To identify the of Conflict management styles corresponding to each sources of conflict.

\subsection{Hypothesis}

H1: Perceived organizational politics, Perceived uncivil behavior and Perceived organizational injustice do not depend on conflict management styles like integrating style, obliging style, dominating style, avoiding style and compromising style.

\subsection{Methodology}

This study employed survey of service sector employees to gather data with the help of validated survey instrument in the form of questionnaire for hypothesis testing and to address research objectives 660 questionnaires were distributed among them. For the purpose of analyses of the data collected the respondents who did not respond to all questionnaires or for whom there was a suspicion of random response such as use of the identical answer throughout is excluded. A total of 550 respondents met these inclusion criteria and thus, constitute a sample size for the present study. Since, the respondents for the survey were identified on the basis of judgment comprising factors such as conflicting possibilities, individuals in service sector and job complexities, the sampling procedure adopted for the present study is categorized as Judgment sampling method. Three independent multiple regression models are used in the present work to identify the conflict management styles and its effects on the sources of conflicts such as Organizational politics, Uncivil behavior and Organizational injustice. 


\subsection{Questionnaire Design and the Reliability tests}

Questionnaire was framed for the present study comprising the measurement schemes for measuring the variables (a) Demographic profile of the respondents and (b) Source of conflict in service sector. While the provision for recording standard set of details in Demographic profile was incorporated in the Questionnaire, the variables on sources of conflict and conflict management styles were measured with validated 5 point likert scale. Further, the reliability of these scales was ascertained through the values of CronBach Alpha obtained well and above the suggested value of 0.6. (Nunnaly,1978). The specific details of these reliability values corresponding to each scale are shown in Exhibit-1.

Exhibit-1: Details of the Measurement Scales with Corresponding Reliability values

\begin{tabular}{|l|l|l|}
\hline S.No. & Details of the Scale & Cronbach Alpha \\
\hline 1. & Organizational politics (Kacmar and Carlson, 1997) & 0.781 \\
\hline 2. & Uncivil behavior in work place (Martin and Hine, 2005) & 0.898 \\
\hline 3. & Organizational injustice (Colquitt and Rodell, 2011) & 0.886 \\
\hline 4. & Conflict management Styles (Rahim and Magner, 1995) & \\
\hline (i) & Integrating Style & 0.911 \\
\hline (ii) & Obliging Style & 0.876 \\
\hline (iii) & Dominating Style & 0.797 \\
\hline (iv) & Avoiding Style & 0.856 \\
\hline (v) & Compromising Style & 0.756 \\
\hline
\end{tabular}

\section{Data Analysis and Discussions}

\subsection{Perceived Organizational politics and conflict management}

The dependency effects of perceived organizational politics on conflict management styles like integrating style, obliging style, dominating style, avoiding style and compromising style is defined in hypothesis-1, taken up and its results are shown in the table-1, as an outcome of regression model conceptualized. From the results, it can be inferred that the F value of 38.225 is found to be significant at 5 percent level.

Table-1:Organizational Politics and the resultant Conflict Management styles

\begin{tabular}{|c|c|c|c|c|c|c|}
\hline \multirow[t]{2}{*}{ Model } & \multicolumn{2}{|c|}{$\begin{array}{l}\text { Unstandardized } \\
\text { Coefficients }\end{array}$} & \multirow{2}{*}{$\begin{array}{l}\text { Standardized } \\
\text { Coefficients } \\
\text { Beta } \\
\end{array}$} & \multirow[t]{2}{*}{$\mathbf{t}$} & \multirow[t]{2}{*}{$\mathbf{F}$} & \multirow[t]{2}{*}{$\begin{array}{l}\text { Adjusted } \\
\text { square }\end{array}$} \\
\hline & B & Std. Error & & & & \\
\hline (Constant) & 32.471 & 1.355 & & $23.956^{*}$ & \multirow[t]{6}{*}{$38.225^{*}$} & \multirow[t]{6}{*}{0.590} \\
\hline Integrating style & 0.369 & 0.094 & 0.235 & $3.929 *$ & & \\
\hline Obliging style & 0.158 & 0.102 & 0.091 & 1.541 & & \\
\hline Dominating style & 0.149 & 0.108 & 0.085 & 1.387 & & \\
\hline Avoiding style & 0.160 & 0.150 & 0.061 & 1.064 & & \\
\hline Compromising style & 0.025 & 0.120 & 0.012 & 0.208 & & \\
\hline
\end{tabular}

These results suggest that conflict resolution strategies on perceived organizational politics depends on conflict management styles such as integrating style, obliging style, dominating style, avoiding style and compromising style. Further, the adjusted R square value of 0.590 from the table-1 indicates that 59 percent of conflict resolution strategies on perceived organizational politics among employees in service sector is significantly dependent on these conflict management styles. Also, the ' $t$ ' value of 3.929 corresponding to the Integrating style is found to be having significant effect on the model conceived.

More specifically Integrating style is found to be having significant superior effect in resolving conflicts due to perceived organizational politics with highest' $t$ ' value of 3.929. However, the ' $t$ ' values of 1.541, $1.387,1.064$ and 0.208 corresponding to obliging style, dominating style, avoiding style and compromising style are not found to be significant at 5 percent level. Hence, it can be inferred that the conflict resolution strategy due to perceived organizational politics do not depend on conflict management styles like obliging style, dominating style, avoiding style and compromising style in the regression model conceived.

\subsection{Perceived Uncivil Behavior and conflict management}

The dependency effects of perceived uncivil behavior on conflict management styles like integrating style, obliging style, dominating style, avoiding style and compromising style is defined in hypothesis-1, taken up and its results are shown in the table-2, as an outcome of regression model conceptualized. 
Table-2: Uncivil behavior and the resultant Conflict Management styles

\begin{tabular}{|c|c|c|c|c|c|c|}
\hline \multirow[t]{2}{*}{ Model } & \multicolumn{2}{|c|}{ Unstandardized Coefficients } & \multirow{2}{*}{$\begin{array}{l}\text { Standardized } \\
\text { Coefficients } \\
\text { Beta } \\
\end{array}$} & \multirow[t]{2}{*}{$\mathbf{t}$} & \multirow[t]{2}{*}{$\mathbf{F}$} & \multirow{2}{*}{$\begin{array}{l}\text { Adjusted } \\
\text { R square }\end{array}$} \\
\hline & $\mathbf{B}$ & Std. Error & & & & \\
\hline (Constant) & 28.884 & 1.838 & & $15.719 *$ & \multirow[t]{6}{*}{$57.223^{*}$} & \multirow[t]{6}{*}{0.623} \\
\hline Integrating style & 0.531 & 0.127 & 0.238 & $4.173^{*}$ & & \\
\hline Obliging style & 0.329 & 0.139 & 0.133 & $2.370^{*}$ & & \\
\hline Dominating style & 0.380 & 0.146 & 0.153 & $2.605^{*}$ & & \\
\hline Avoiding style & 0.081 & 0.204 & 0.022 & 0.396 & & \\
\hline Compromising style & 0.054 & 0.163 & 0.018 & 0.333 & & \\
\hline
\end{tabular}

From the results, it can be inferred that the $\mathrm{F}$ value of 57.223 is found to be significant at 5 percent level. These results suggest that conflict resolution strategies on perceived uncivil behavior depends on conflict management styles such as integrating style, obliging style, dominating style, avoiding style and compromising style among employees. Further, the adjusted R square value of 0.623 from the table- 2 indicates that 62 percent of conflict resolution strategies on perceived uncivil behavior is significantly dependent on these conflict management styles. Also the ' $t$ ' values of 4.173, 2.370 and 2.605 corresponding to the factors integrating style, obliging style and dominating style are found to be having significant effect on the model conceived.

More specifically integrating style among employee is found to be having significant superior effect in resolving conflicts due to perceived uncivil behavior with highest' $t$ ' value of 4.173. Similarly, dominating style among employee is found to be having significant good effect in resolving conflicts due perceived uncivil behavior in service sector with the next higher $t$ value of 2.605 . The ' $t$ ' value of 2.370 obtained for the obliging style significantly causes considerable effect in resolving conflicts due perceived uncivil behavior in service sector.

However, the ' $t$ ' values of 0.396 and 0.333 corresponding to avoiding style and compromising style are not found to be significant at 5 percent level. Hence, it can be inferred that the conflict resolution strategies due to perceived uncivil behavior do not depend on conflict management styles like avoiding style and compromising style.

\subsection{Perceived Organizational Injustice and conflict management}

The dependency effects of perceived organizational injustice on conflict management styles like integrating style, obliging style, dominating style, avoiding style and compromising style is defined in hypothesis-1, taken up and its results are shown in the table-3, as an outcome of regression model conceptualized. From the results, it can be inferred that the F value of 42.812 is found to be significant at 5 percent level.These results suggest that conflict resolution strategies on perceived organizational injustice depends on conflict management styles like integrating style, obliging style, dominating style, avoiding style and compromising style.

Table-3: Organizational Injustice and the resultant Conflict Management styles

\begin{tabular}{|c|c|c|c|c|c|c|}
\hline \multirow[t]{2}{*}{ Model } & \multicolumn{2}{|c|}{$\begin{array}{l}\text { Unstandardized } \\
\text { Coefficients }\end{array}$} & $\begin{array}{l}\text { Standardized } \\
\text { Coefficients }\end{array}$ & \multirow[t]{2}{*}{$\mathbf{t}$} & \multirow[t]{2}{*}{$\mathbf{F}$} & \multirow[t]{2}{*}{$\begin{array}{l}\text { Adjusted } \\
\text { R square }\end{array}$} \\
\hline & B & Std. Error & Beta & & & \\
\hline (Constant) & 77.333 & 1.943 & & $39.797^{*}$ & \multirow[t]{6}{*}{42.812} & \multirow[t]{6}{*}{0.549} \\
\hline Integrating style & -0.621 & 0.135 & -0.273 & $-4.612^{*}$ & & \\
\hline Obliging style & -0.417 & 0.147 & -0.165 & $-2.840 *$ & & \\
\hline Dominating style & -0.085 & 0.154 & -0.033 & -0.551 & & \\
\hline Avoiding style & -0.070 & 0.216 & -0.018 & -0.324 & & \\
\hline Compromising style & -0.029 & 0.173 & -0.010 & -0.169 & & \\
\hline
\end{tabular}

Further, the adjusted R square value of 0.549 from the table- 3 indicates that 54 percent of conflict resolution strategies on perceived organizational injustice among employees in service sector is significantly dependent on these groups of factors. Also the ' $t$ ' values of -4.612 and -2.840 corresponding to the factors integrating style and obliging style are found to be having significant effect on the model conceived.

More specifically integrating style among employee is found to be having significant superior effect on perceived organizational injustice with a ' $t$ ' value of -4.612. The negative ' $t$ ' value obtained indicates the existence of inverse relationship between existence of perceived organizational injustice and the conflict resolution strategies such as integrating style. Also, the significant negative' $t$ ' value of -2.840 obtained for the conflict management style of the type obliging confirms the existence of similar such inverse relationship. Based on the results obtained for the above three independent multiple regression models shown in table-1,2 and table- 3 , the 
hypothesis 1 taken up for the present work is rejected. These results forms the basis to confirm the existence of dependency relationship between the conflict sources such as Perceived organizational politics, Perceived uncivil behavior, Perceived organizational injustice and the conflict resolution strategies such as like integrating style, obliging style, dominating style, avoiding style and compromising style in services settings.

\section{Findings}

1. Perceived conflict sources such as organizational politics, uncivil behavior and organizational injustice significantly depend on the conflict resolution strategies adopted by the employees in services settings. The conflict resolution strategies adopted include conflict management styles such as like integrating style, obliging style, dominating style, avoiding style and compromising style.

2. All the three perceived conflict sources have specific significant levels of dependency with a conflict management style of the type Integrating. Whereas the perceived conflict source such as uncivil behavior has specific significant levels of dependency with a conflict management styles of the type obliging and dominating in addition to the specific levels of dependency it has with the conflict management style of the type integrating..

3. Organizational injustice as a specific perceived source of Organizational conflict has significant inverse levels of dependency with conflict resolution strategies such as integrating style and the obliging style. This confirms significantly decreasing levels of adoption of these two conflict management styles under the conditions of perceived conflict source like organizational injustice.

\section{Implications and Conclusions}

The existence of dependency relationship between conflict sources and the conflict management style adopted by the employees in services settings gives scope for services enterprises to identify the sources of conflict by measuring the levels of various conflict management styles adopted by the employees. This kind of strategy will help the services enterprises to identify the conflict sources indirectly without compromising the environmental rigidity which could form the potential control parameter in organizations. For instance, the services enterprises can identify the existence of higher perceived organizational injustice with lower levels of adoption of conflict management styles such as integrating style and obliging styles. Similarly, higher levels of adoption of conflict management styles such as Integrating and Dominating in services setting could act as reference check for services enterprises to identify and potentially deal with the conflict sources such as perceived organizational politics and uncivil behavior in work place.

\section{References}

[1]. Alper, S., Tjosvold, D., and Law, K. S. (2000). Conflict management, efficacy, and performance in organizational teams. Personnel Psychology, 53(3), 625-642.

[2]. Andersson, L. M., \& Pearson, C. M. (1999). Tit for tat? The spiraling effect of incivility in the workplace. Academy of Management Review, 24, 452-471.

[3]. Baron, R., and Joel, N. (1996). Workplace Violence and Workplace Aggression: Evidence on their Relative Frequency and Potential Causes. Aggressive Behavior, 22 (May/June), 161-173.

[4]. Caza, B. B., \& Cortina, L. M. (2007). From insult to injury: Explaining the impact of incivility. Basic and Applied Social Psychology, 29(4), 335-350.

[5]. Chen, G., and Tjosvold, D. (2002). Conflict management and team effectiveness in China: The mediating role of justice. Asia Pacific Journal of Management, 19(4), 557-572.

[6]. Colquitt, J. A., \& Rodell, J. B. (2011). Justice, trust, and trustworthiness: A longitudinal analysis integrating three theoretical perspectives. Academy of Management Journal, 54(6), 1183

[7]. Cortina, L. M., Magley, V. J., Williams, J. H., \& Langhout, R. D. (2001). Incivility in the workplace: Incidence and impact. Journal of Occupational Health Psychology, 6, 64-80.

[8]. Cosier, R. A., and Ruble, T. L (1981). Research on conflict-handling behavior: An experimental approach. The Academy of Management Journal, 24(6) 816-831.

[9]. Drory, A. and Romm, T. (1988). Politics in organization and its perception within the organization. Organization Studies, 9(3), 165179 .

[10]. Eisenberger, R., Huntington, R., Hutchison, S. and Sowa, D. (1986). Perceived organizational support. Journal of Applied Psychology, 71(8), 500-507.

[11]. Ferris, G. R. and Kacmar, K. M. (1992). Perceptions of organizational politics. Journal of Management, 18, $93-116$.

[12]. Ferris, G. R., Frink, D. D., Galang, M. C., Zhou, J., Kacmar, K. M. and Howard, J. E. (1994). Perceptions of organizational politics: predictions, stress-related implications, and outcomes. Human Relations, 48(10), 49-82.

[13]. Gandz, J. and Murray, V. V. (1980). The experience of workplace politics. Academy of Management Journal, 23(9), 237-251.

[14]. Goddard, A. (1999). Culture and Drama: The role of financial control systems in the organisational processes in three local government organisations. The International Journal of Public Sector Management, 12(6), 516-532.

[15]. Kacmar, K. M., \& Carlson, D. S. (1997). Further validation of the perceptions of politics scale (POPS): A multiple sample investigation. Journal of management, 23(5), 627

[16]. Kanten, P., \& Ülker, F. E. (2013). The effect of organizational climate on counterproductive behaviors: an empirical study on the employees of manufacturing enterprises. The Macrotheme Review, 2(4), 144

[17]. Konovsky, M. A. (2000). Understanding procedural justice and its impact on business organizations. Journal of Management, 26, 489-511. 
[18]. Lam, S. S. K., Schaubroeck, J., \& Aryee, S. (2002). Relationship between organizational justice and employee work outcomes: a cross-national study. Journal of Organizational Behavior, 23(6), 1-18.

[19]. Martin, R. J., \& Hine, D. W. (2005). Development and validation of the uncivil workplace behavior questionnaire. Journal of occupational health psychology, 10(4), 477.

[20]. Masterson, S. S., Lewis, K., Goldman, B. M., \& Taylor, M. S. (2000). Integrating justice and social exchange: the differing effects of fair procedures and treatment on work relationships. Academy of Management Journal, 43(9), 738-748.

[21]. Nunnally,J. (1978). Psychometric Methods. New York: McGraw-Hill

[22]. Patterson, M. G., West, M. A., Shackleton, V. J., Dawson, J. F., Lawthom, R., Maitlis, S., ... \& Wallace, A. M. (2005). Validating the organizational climate measure: links to managerial practices, productivity and innovation. Journal of organizational behavior, 26(4), 379

[23]. Pearson, C. M., Andersson, L. M., \& Porath, C. L. (2000). Assessing an attacking workplace incivility. Organizational Dynamics, 29, 123-137.

[24]. Rahim, M. A., \& Magner, N. R. (1995). Confirmatory factor analysis of the styles of handling interpersonal conflict: first-order factor model and its invariance across groups. Journal of applied psychology, 80(1), 122.

[25]. Rahim, M. A., and Antonioni, D., and Psenicka, C. (2001). A structural equations model of leader power, subordinates' styles of handling conflict, and job performance. International Journal of Conflict Management, 12(3), 191-211.

[26]. Rahim, M.A. (1983). A Measure of Styles of Handling Interpersonal Conflict, Academy of Management Journal, 26(2), 368-376

[27]. Rahim, M.A. (1985). A strategy for managing conflict in complex organizations. Human relation, 38(7) 81-89.

[28]. Rahim, M.A. and Bonama, T.V. (1979). Managing organizational conflict: A model for diagnosis and intervention. Psychological Reports, 44(5), 1323-1344.

[29]. Rahim, M.A., Magner, N.R., \& Shapiro, D.L. (2000). Do justice perceptions influence styles of handling conflict with superiors? What justice perception, precisely. International Journal of Conflict Management, 11(1), 9-31.

[30]. Sarros, J. C., Gray, J., Densten, I. L., \& Cooper, B. (2005). The organizational culture profile revisited and revised: An Australian perspective. Australian Journal of Management, 30(1), 159

[31]. Singh, J. (2000). Performance Productivity and Quality of Frontline Employees in Service Organizations. Journal of Marketing, 64 (April), 15-34.

[32]. Suppiah, W., and Rose, R. (2006). A competence-based view to conflict management. American Journal of Applied Sciences, 3(7), 1905-1909.

[33]. Tjosvold, D., Law, K., and Sun, H. (2006). Effectiveness of Chinese teams: The role of conflict types and conflict management approaches. Management and Organization Review, 2(2), 231-252.

\section{Appendex-Questionnaire}

\section{Sno.Organizational Politics}

1 People in this organization attempt to build themselves up by tearing other down.

2 There has always been an influential group in this organization that no one ever crosses.

3 In this employees are not encouraged to speak out frankly even they are critical of well established ideas.

4 There is no place for yes-men around here; good ideas are not desired even if it means disagreeing with superior.

5 Agreeing with powerful others is the best alternative in this organization.

6 It is best not to rock the boat in this organization.

7 Sometimes it is easier to remain quite than to fight the system in this organization.

8 Telling others what they want to hear is sometimes better than telling the truth.

9 It is safer to think what you are told than to make up your mind.

10 Since the time I have worked in this organization, I have never seen the pay and promotion policies applied with disparity.

11 I feel some person in this organization receive pay increase or promotion that was inconsistent with the published policies.

12 None of the pay increase I have received is consistent with the policies on how pay raises should be determined in this organization.

13 The stated pay and promotion policies have nothing to do with how pay raises and promotions are determined.

14 When it comes to raise pay and promotion decisions, policies are irrelevant in this organization.

15 Promotions in this organization are not valued much because how they are determined is so political.

Sno.Uncivil Behavior in work place

1 People avoided consulting you when they would normally be expected to be so in your workplace.

2 People talking behind your back in your work place.

3 Excessively slow in returning your communications without good reason for the delay in your work place.

4 Experienced an inappropriate tone when speaking to you in your work place.

5 Was unreasonably slow in dealing with matters that were important to your work.

6 People gossip behind your back in your work place.

7 Someone opened your desk drawer without your prior permission in your work place.

8 Somebody publicly discussed your confidential personal information in your work place.

9 Someone took items from your desk without your prior permission in your work place.

10 Someone spoke to you in an aggressive tone of voice in your work place. 
11 Intentionally failed to pass on information that you should have been made aware of in your work place.

12 Someone made snide remarks about you in your work place.

13 Someone took stationary from your desk without later returning it in your work place.

14 Someone read communications addressed to you such as mails and faxes in your work place.

15 Someone raised voice while speaking to you in your organization.

16 No one consult you in reference to a decision you should have been involved in your work place.

17 Someone rolled their eyes at you in your work place.

Sno.Organizational Injustice

1 Are you able to express your views during the procedure in your organization.

2 You can influence the decisions arrived at by those procedures in your organization.

3 Procedure are applied consistently in your organization.

4 Procedures are free of bias in your organization.

5 Procedures are based on accurate information in your organization.

6 You're able to appeal the decisions arrived at those procedures in your organization.

7 Procedures uphold ethical and moral standards in your organization.

8 Outcomes are reflecting the effort you have put into your work in your organization.

9 Outcomes are appropriate for the work you have completed in your organization.

10 Outcomes reflect what you have contributed to your work in your organization.

11 Outcomes justified your performance in your organization.

12 Your superior treated you in a polite manner in your organization.

13 Your superior treated you with dignity in your organization.

14 Your superior treated you with respect in your organization.

15 Your superior refrained from improper remarks or comments in your organization.

16 Your superior has been candid when communicating with you in your organization.

17 Your superior explained decision-making procedure thoroughly in your organization.

18 Your superior explanations regarding procedures reasonably in your organization.

19 Your superior communicated details in timely manner in your organization.

20 Your superior tailored communications to meet individual needs in your organization.Conflict Management styles

Sno.Integrating Style

1 In my job I try to investigate an issue with my superior to find a solution acceptable to us.

2 in my job I try to integrate my ideas with those of my superior to come up with a decision jointly.

3 In my job I try to work with my superior to find solutions to problems which satisfy our expectations.

4 In my job I exchange accurate information with my superior to solve a problem together.

5 In my job I try to bring all our concerns out in the open so that the issue can be resolved in the best possible way.

6 In my job I collaborate with my superior to come up with a decision acceptable to us.

7 In my job I try to work with my superior for a proper understanding of a problem.

Sno.Obliging Style

1 In my job I generally try to satisfy the needs of my superior.

2 In my job I give into the wishes of my supervisor.

3 In my job I usually allow concessions to my superior.

$4 \quad$ In my job I often go with other suggestions of my superior.

5 In my job I try to satisfy the expectations of my supervisor.

6 In my job I usually accommodate the wishes of my superior.

Sno.Dominating Style

1 In my job I use my influence to get my ideas accepted.

2 In my job I use my authority to make decisions in my favor.

3 In my job I use my expertise to make decisions in my favor.

4 In my job I am generally firm in pursuing my side of the issue.

5 In my job I sometimes use my power to win a competitive situation.

Sno.Avoiding Style

1 In my job I attempt to avoid being "put on the spot" and try to keep my conflict with my superior to myself.

2 In my job I avoid open discussions of my difference with my superior. 
3 In my job I try to stay from disagreement with my superior.

$4 \quad$ In my job I avoid an encounter with my superior.

5 In my job I try to avoid my disagreement with my superior to myself in order to avoid hard feelings.

6 In my job I try to avoid unpleasant exchanges with my superior.

Sno.Compromising Style

1 In my job I try to find a middle course to resolve an impasse.

2 In my job I usually propose a middle ground for breaking deadlocks.

3 In my job I negotiate with my superior so that a compromise can be reached.

4 In my job I use "give and take" so that compromise can be made. 